\title{
The Finagling Art of Historical Fiction
}

\author{
Stephan Paul Bortolotti \\ Department of General Education, Midstate College, Illinois, USA
}

Copyright (C) 2015 Horizon Research Publishing All rights reserved.

\begin{abstract}
Historical fiction is a sub-genre of fiction, not history, since it often portrays fictional accounts or dramatization of historical figures or events. Historical fiction presents readers with stories that take place during a notable period in history and usually during a significant event in that period. Historical fictionists misrepresent historical "fact" in an attempt to achieve a certain artistic effect: to capture the social and cultural conditions of the people in a given time, with particular attention paid to accurate contemporary details often ignored by historians. This paper explores reasons why writers of historical fiction employ certain tactics when they write, such as lying and manipulating. Finagling an audience ties directly into Brown and Levinson's definition of Negative Face and so this paper also explores the intersection of B/L's politeness theory and creative writing, specifically how the relationship that exists between interlocutors in oral communication mirrors the same relationship between author and reader in creative fiction.
\end{abstract}

Keywords Historical Fiction, Fabulation, Brown and Levinson, Politeness Theory, Negative Face

\section{Introduction}

Historical fiction: the name of the genre is problematic for it is oxymoronic. Often when people hear the term "historical fiction" they think that it is not only a sub-category of fiction, which it should be, but also a sub-category of history, or it at least should be. But history is not objective truth and fiction is not the opposite of truth. And while "fiction" suggests "created by imagination," there is plenty of evidence in literature that the imagination can get as close to truth as any fact-finding mission can. Even the terms that have been used to qualify historical fiction as a genre indicate some critics are fully aware it is not a reliable, factual history, hence the labels "romance, anti-history" and "fictive nonfiction." Clearly, there is much confusion rather than a successful viewing of the dialectic involved. So if historical fiction is not a reliable history, why write it and not a pure history? How related or unrelated are historical fiction and recorded history anyway? Can we automatically assume that recorded history is factual and historical fiction authors should not be allowed to take literary license with historical "facts," or is it ethical that they lie or "fabulate"? And is it ethical that historical fiction authors manipulate historical events, and in turn, finagle their readers to suit their own needs? If historical fiction is a legitimate literary form, what distinguishes the genre, and just what is its place in the literary canon? The answers to these questions can be found by studying the relationship between author and reader, more specifically, between historical fictionists and the audiences they finagle through lying and manipulation.

\section{The Writer as Fabulator}

Some have argued that the tendency to write historical fiction is a result of the influence of postmodernism resulting in the destabilization of a traditionally academic history. If factuality of "historical facts" or the integrity of sources are problematical, and the historians' interpretations are seen as crucial, if questionable, in constructing their version of the past, then the contemporary historical fiction authors' blurring of the lines between fact and fiction, history and narrative, is part of that destabilization.

Etymologically speaking, both the words history and story derive from the same word historia, and originally both words were defined as an account of either imaginary events as well as events supposed to be true. The two words have since evolved separately so that history has come to mean an account of past real events and story refers to less formal accounts of past events and accounts of fictional events. As a result, this etymological evolution has allowed some contemporary novelists on the one hand to regard history as unreliable, and on the other hand to regard fiction as another way of writing history, of offering a substitute for it, or even creating an alternative history. Simply stated, a true historical novel will offer an account of the past which it purports to be true, even claiming to correct or substitute for authorized history, but which all too well aware of its own [mis]representation of that truth.

Historical fiction is often the domain of historians turned novelists, or of military men and women who have decided to write a novel, in which case they are often categorized as "war" novels rather than the less impressive "historical 
fiction." The popularity of historical fiction may have something to do with the public's recurring appreciation of the genre of history in general. But in some camps, historical fiction's reputation is diminished because of its close association with the genre of history and the liberties it takes with recorded "truths." Historical fiction is often viewed as an inherently inferior genre in academia.

This prejudice against historical fiction may stem from the perception that it is just another sub-category of history, a subject many people learned to dread in school. But even if historical fiction is a sub-category of history, according to Paul Levine [1], E. L. Doctorow tempers this attitude by saying "history is a kind of fiction in which we live and hope to survive. And fiction is a kind of speculative history, perhaps a superhistory, by which data for the composition is seen to be greater and more various in its sources than the historian supposes."

In historical fiction, the basic dimensions of culture -

the political, aesthetic, and cognitive - all converge to give

the reader a sense of truth and authenticity. The hybrid amalgamation of history and imagination helps to render a representation of the past while at the same time acting as an instructional and inspirational literature tool. The retelling of historical "fact" inevitably ends in storytelling; therefore, in order to be regenerated, historical "fact" becomes historical "fiction." Fiction thus becomes not the opposite of fact, but rather its counterpart.

To be sure, readers may grapple with the honesty of historical fiction and tentatively walk the fine line between contemporary sensibilities and historical accuracy. However, it is important to stress that a keen critical perception is needed in the successful writing and reading of historical fiction, for historical fiction can and should be viewed contextually as a dialectical between the bias, social actions, and mores of the past, with those in the world of the contemporary reader. Fictionalizing history is an attempt to reimagine the past so that it more closely mirrors the present. This fictionalizing of history - this fabulating, if you will - is the motivation and inspiration of the historical fictionist.

Often critics complain that in some pieces of historical fiction fact is not clearly distinguishable from invention; therefore, these works fail in one of their principal goals, which is a faithful representation of a chapter or epoch in history. Italian novelist Alessandro Manzoni [2] (1785 1873), one of the first to explore the rise and fall in popularity of the historical novel, claimed that the goals of historical fictionists do not include an accurate representation of historical events based on empirical evidence, but "a more general representation of the human condition." Besides, we often assume written history is an accurate representation of what happened in the past, and that is simply not the case. Each generation revisits and rewrites history by claiming previous experts were inaccurate or perhaps that newly uncovered evidence forces a rewrite of what had come to be considered historical fact. History, therefore, becomes tailored to an audience and to a time, and it becomes, as cultural critic Jerome de Groot [3] puts it, "innately textualized [sic] and therefore questionable because signifier and signified do not map on to each other ... [history has become] a set of narrative tropes." Most histories are based on an interpretation of a combination of scientific and archaeological data, thus historical records are more like an historian's judgment of a period, which is precisely what the writers of historical fiction incorporate into their bodies of work.

Sometimes these "judgments" are viewed by critics as reinterpreting historical "fact" too liberally, and in some camps it is seen as flat out lying. The term "lie" carries heavy negative connotations, so by resurrecting the term "fabulator" into the dialectic, Robert Scholes [4] hoped to diffuse the stigma and resulting controversy for authors who elect to manipulate "true" historical data and reinterpret it for their fiction. Scholes writes that the term "fabulator" grew out of a need for scholars to define a "movement of great importance in contemporary fiction that lacked a name." This postmodern movement was a type of "fictional propriety derived from a version of realism."

This new fiction - this fabulation - is actually based on fables of old which took an "enormous delight" in its ability to design its own form. In fact, Scholes argued that "a sense of pleasure in form is one characteristic of fabulation." According to Scholes, the distinct form of fabulated writing "asserts the authority of its shaper," such as we will see below in the discussion on Scheherazade and the Sultan. Scholes notes, "Delight in design and in its concurrent emphasis in the art of the designer, which will distinguish the art of the fabulator from the work of the novelist or the satirist. Of all narrative forms, fabulation puts the highest emphasis on art and joy."

Modern fabulation is closely related to a post-modern reaction to "fallibilism."1 Fabulation is an attempt to find a better connection to, as phrased by Scholes, "the reality which is fiction and the fiction which is reality." The goal of the fabulator is to tell such truths as fiction may "legitimately tell in ways that are appropriately fictional." This is the primary goal of the historical fictionist as well, who seeks a closer tie to historical truth through a revisionary approach.

This constant revising of written history results in our questioning its objectivity. One view of the reliability of historiography comes from British journalist and radical theorist Edward Hallett Carr [5] whose historiographical principles rejected traditional historical methods and practices. Carr argues that the belief in hard core historical facts existing objectively and independently of the interpretation of the historian is a preposterous fallacy and it "simply will not do." Carr correctly posits that since such a mountain of data exists, historians always choose the facts they decide to utilize for a particular agenda while ignoring

1 "Fallibilism": the philosophical doctrine that absolute certainty about knowledge is impossible; or at least that all claims to knowledge could, in principle, be mistaken. 
others that don't fit that agenda: "The (historical) facts speak only when the historian calls on them; it is he who decides which facts to give the floor, and in which order or context."

Take such obvious examples involving American presidential biographies. How often have history books discussed Thomas Jefferson's illegitimate children by his slave Sally Hemmings? Or that Abraham Lincoln suffered from lifelong manic depression? How many history books have suggested that James Buchanan was a homosexual, which he almost certainly was? These historical facts fly in the face of how we regale and revere our dead presidents, and so historians have decided to ignore them or sugarcoat them. Carr claimed that only morally accepted, sanitized "historical facts" are declared noteworthy by historians. According to Carr, information that historians deem unimportant, inappropriate, or impede a particular objective, are lumped into a category that he called "facts of the past." Carr contended that historians often arbitrarily determine which of the "facts of the past" will evolve into "historical facts" based on their own biases, agendas, or pressure from interest groups. Hence, pressure from African-Americans has resulted in uncovering the truth about Jefferson's relationship with Hemmings. Interest groups such as psychiatrists and gay liberators "out" Lincoln and Buchanan. Certainly it is not wrong that they these groups demand the truth be told. On the contrary.

Another example of historical fact fitting an agenda is the story of Betsy Ross creating the first American flag at the behest of General George Washington, "the most tenacious piece of fiction involving the [US] flag," as reported by the Washington Post. The Post states that while in Philadelphian Ross did make flags in the late 1770s, "it is all but certain that the story about her creating the American

flag is a myth." The story was propagated from a piece of Ross family lore and was so popular it eventually became cemented into the American folklore canon. In an interesting twist, the Betsy Ross myth illustrates how a lie can evolve into a piece of historical fiction so imbedded in our national consciousness that any challenge by truthful, factual historiography is near treasonous. The Ross historical fiction also proved profitable in 1893 when Charles H. Weisberger, artist and opportunist immortalized the scene in a painting entitled "The Birth of Our Nation's Flag" and reaped big economic reward from the legend.

All this is not to suggest that most of history is based on lies, rather it is to suggest that there is no such thing as a pure objective history. Carr states, "The facts of history cannot be purely objective, since they become facts of history only in virtue of the significance attached to them by the historian." That doesn't mean recorded history is invalid or untruthful, but it is "a type of propaganda," as historiographer and iconographer Linda Schele [6] suggests. But by history constantly being rewritten, reevaluated, and redrawn, we begin to question which version(s) of history to believe. That is where the historical fictionist comes in. After all, if much of history itself is founded on subjective "truths," then historical fiction writers are not really bastardizing or taking too much liberty with history at all. When history is constantly rewritten, reevaluated and redrawn, we begin to question which version(s) of history to believe.

Whereas historical sources may be able to speculate where historical figures were on a given day, what they said or did, recorded history does remain, to a certain degree, speculative. Accordingly, historians are almost never able to say in truth what these people felt, which should be a primary goal of historical fiction. Oddly, the two are not as far different as one might think. The fictionist and the historian are using the same tool to reach the same outcome: a narrative style to interpret and imagine the past.

Furthermore, the leap into the imagination is the same for the historian and as it is for the historical fiction writer. Literary theorist Linda Hutcheon [7] claims that both history and fiction are discourses and the authors of each, by writing the past, necessarily construct it. Hutcheon believes that the narrativization of history further undermines its truth claim because it is tantamount to fictionalization. And while both fiction writer and historian imagine/reimagine the past, the difference is that the writer calls this account "fiction" while the historian calls it "speculation." Good writers of historical fiction take a look at historical "facts" and then use their imaginations to embellish history into the basis for their stories. But of course, in spite of these few similarities, historical fiction is profoundly different from a history proper in all other aspects, for as Manzoni points out, "its aesthetic and ethical problems are far more complex."

But what else differentiates historical fiction from pure history? One difference is the level at which the respective authors seek the truth, what motivates this search, and what tools they employ to achieve the desired end result. Historians seek to answer the question "What happened?" and therefore they turn to empirical data. Writers of historical fiction seek to explain "What was it like?" and therefore they manipulate empirical data ... they fabulate; they lie. Historians focus on the events. Writers of historical fiction focus on the persons (the story's life-like characters) involved while at the same time fictionalizing those events. Joanne Brown and Nancy St. Clair [8] maintain that "most readers of historical fiction usually assume that a historical novel ... has a certain authenticity or that it conveys the 'truth' about a certain period or event - if not a literal truth then an emotional one. Yet, writers of historical fiction must find a balance between the historicizing fiction and fictionalizing history."

Authors such as Truman Capote in his ground-breaking piece of fictive nonfiction In Cold Blood (1966) wanted it both ways, or, as John Holloway [9] puts it, "the impeccable accuracy of fact and the emotional impact found only in fiction." In his book, Capote built a traditional narrative structure around factual events, selecting and arranging des temps forte 2 for maximum effect, while at the same time

2 Literally "the strong moments" 
giving fictitious names to the murderers and their victims. There is a certain artifice when authors choose des temps forte, their historical "significant moments," but to accomplish this action, many events are chosen while others are not. Call it artifice, call it lying, prevaricating, or fabulating, but capitalizing on these moments and choosing them for maximum dramatic and emotional effect are the historical fiction writer's goals. Authors such as Fyodor Dostoevsky, Meyer Levin, Theodore Dreiser, Capote and Doctorow are just a few authors who were quite successful at achieving this balance.

And they all lied.

Dostoevski (Crime and Punishment, 1866) and Dreiser (American Tragedy, 1925) manipulated actual case material for their own literary needs. And just as these authors and others have done, Levin in his book Compulsion (1956) also recycled and "revisioned" published news documentation, in this case the Leopold-Loeb murders in 1920s Chicago, but, as Holloway states, "he was more forthright than most historical fiction writers when he claimed more poetic license with the facts." Many of Levin's scenes are factual, others are fabulations. Levin himself said that his book could be called either "an historical novel or a documentary novel." But books such as In Cold Blood and Compulsion are literary works since both clearly are products of the authors' imaginations. What authors such as Capote and Levin have done is what good authors of fiction strive to do: they visit events of the past and combine techniques of novel writing with fabulation resulting in a unique literary form.

While books such as Compulsion and In Cold Blood are well researched and convincingly written pieces of historical fiction, which Capote himself coined as the "non-fiction novel," they follow a well-established writing tradition. Historical fiction is the most basic, the most natural of literary forms, the first task of which is to create fictional worlds that are alternatives to the past. If one looks at the first stories of any given culture, they are almost always stories about ancestors and forefathers. But historical fiction has always been a literary form at odds with itself. The very term - which implies a fiction somehow grounded in fact, or at worst a lie with tenuous obligations to the truth - is suggestive of the problematic duality of the genre.

Much of historical fiction outrages mimetic critics who feel its writers should not be allowed to "distort" historical fact in books such as Doctorow's Ragtime (1974), which many critics consider a resonating blend of events lifted from the chronicle of the day. Lubmír Doležel [10] argues that mimetic critics "feel compelled to compare historical fictions with 'what actually happened' and praise the fiction writers for being 'truthful' to the past or shame them for 'distorting' the past. Mimetic theory fails to account for the so-called realistic historical fictions. It fails quite miserably when called on to account for the modern and the postmodern innovations. Only a semantics of fiction based on the idea of possible worlds can accept and interpret the radical experiments conducted by the postmodern makers of historical fiction.”
A postmodern take on historical fiction suggests that it is a construct based partly on prevarications which allows historical fiction writers, per Doležel, "to blend fictional and non-fictionalized persons, events, and so on, to create fictional documents of the past, to set an invented personal story in a fictionalized social context of the past." This literary flexibility allows for untold and absolute freedom in the postmodern literary world. Indeed, writers of historical fiction adapt a non-essentialist rhetoric that allows them to change even the most well-documented historical event or person. The historical fiction writer transgresses the rules of fiction writing by contradicting empirical data.

Fiction is not an attempt to record the actual truth, though all fiction - including historical fiction - needs to appear to be "true," according to its own rules. All fiction genres have that in common. But, historical fiction writers, unlike writers of traditional fiction, do not write fictions that correspond to the historical record; or as Doležel states, "they create possible alternative pasts ... a game of aesthetic imagination." In this regard, historical fiction might appear to be simply falsified history. However, whereas falsified or subjective history often serves suspicious entrepreneurial or political purposes - as we have seen in the Betsy Ross and dead president examples - historical fiction, with all of its prevarications, thrusts the reader into a fictional truth and a suspension of disbelief, just as fiction is meant to do. As Richard Lee [11] contends, "Fictional truth has more to do with the suspension of disbelief than with anything scientific or objective. Truth, in fiction, is no more and no less than what you can make your reader believe. And in fact, as far as historical fiction is concerned, it is sometimes easier to make the reader believe in something entirely made up than in something that you have discovered by painstaking research."

Though I will not venture too deeply into a philosophical maelstrom, suffice it to say that truth is, after all, subjective. Henry Ford defined history as "bunk," and Napoleon called it "a lie agreed upon." And though historical fiction cannot be cited as purely authoritative, historical fiction writers get beyond the idea that readers simply do not know for sure whether or not our forebears were the same as us or different. Other genres must be founded in truth, such as memoir writing - just ask James Frey, exposed for his memoir's "inaccuracies" by Oprah Winfrey on her nationally syndicated talk show - but writers of historical fiction can fabulate more, they can take more license because their goals are different from other fiction writers. Writers of historical fiction reveal the past in ways readers often never have thought about; they manipulate their readers, for they want them to feel a certain effect, not to allow them to choose how to feel (more related to this in the Scheherazade section below). Readers of historical fiction are being set up, but ironically, most of them know they are being set up, and an author's fabulations are part of that hook.

Because it takes such liberties with historical "facts," historical fiction may be perceived as having weaker story 
lines compared to other mainstream fiction. The challenge when writing historical fiction is indeed not to allow plot to be overwhelmed by an overabundance of true-to-period details. Leaning too heavily on background will produce a book that is more or less a guided tour of the period. Research of a period is absolutely imperative to the success of historical fiction, but one must never forget that a good piece of historical fiction must also be good fiction. Good fiction or not, the issue that divides historical fiction from other contemporary literature is the matter of historical accuracy: is the story based, in part or all, on a reinterpretation of historical "truths"? Many adhere to the adage that states that "every writer of fiction must be, first and foremost, a liar." But lying is even more necessary for historical fiction writers who write by the mantra: "In creating good historical fiction, it is essential to tell lies," as suggested by historical novelist Glen Craney. [12]

At this point, perhaps it is prudent to make a distinction between telling lies and making mistakes. A literary canard is purposeful, one created to achieve an effect. A literary mistake is accidental, due to poor research, pure laziness, or maybe due to mere neglect or good intentions, though they are sometimes forgivable. An esteemed best-selling author such as Ken Follett was inaccurate when writing The Pillars of the Earth: he described many people of low status regularly eating breakfast, even though very few people in the $12^{\text {th }}$ century would have anything to eat before the main meal of the day at noon. Was this a "mistake" or a "lie"? Either way, a mistake/lie such as this is forgiven and forgotten since Follett continues to be held in such high literary esteem, and readers and critics ask, "Why quibble?" Did James Clavell lie or merely err when he wrote about the closeness of the English pilot Blackthorne and the Shōgun? His story simply is not historically accurate, but in the final analysis it does not matter, for as Craney notes, "[Clavell's prevarications] added to the story; they did not detract from it."

Historical fiction authors, such as Doctorow, who show "a growing impatience with the contemporary novel, especially with the assumed necessity of concealing fiction's ties to reality," according to Naomi Jacobs [13], therefore expand the scope of their aesthetic. Doctorow makes no secret about his use of history in his novels such as Ragtime, wishing to enlarge the scope of his fiction beyond personal and private experience, which he considered, according to Jacobs, a "very small preserve." Indeed, Jacobs quotes Doctorow who viewed his work, with all its "lies" and historical prevarications, as a revenge on the fact-oriented disciplines that have usurped the novelist's storytelling role: "It defies facts. Give "em all sorts of facts; made up facts ... My book is a false document." Doctorow is part of an army of historical fiction writers "who no longer accept accuracy as an obligation or even as a virtue." These writers wisely see history itself as a fiction. Gone are the old standards that prevented authors from inserting lionized historical figures living or dead - into their historical fictions for fear of legal and humanitarian objections. It takes a certain amount of courage to face accusations of exploitation, callousness, or even literary vampirism to portray unfavorably those historical figures that have become - or are destined to become - part of our nation's historical pantheon. And in some cases, as seen in the dead president examples, historical fictionists do no more than what factual history uncovers, or should.

So all this instigates questions: "Why read and/or write historical fiction? If one wants to explore a past era, why not read history books, or visit museums and historic sites? Why rely on an author whose work tells lies about the past?" We write historical fiction, and read it, not to learn about history so much as to live it. It is the closest we can get to experience the past without having been there. We finish reading a history book chapter and we get a sense of what happened. We finish reading a work of historical fiction and we get a sense of what it was like.

University of Albany Professor of English Martha Tuck Rozett [14] writes that by reimagining the past using a historical context the storywriter "performs the analytical role of the historian" by not only identifying in the past the events that impact the future, but also investigating and tracing the process which slowly and steadily produced those events. Rozett cites Umberto Eco (The Name of the Rose, 1983) who contends that the historical fiction author must first construct a world through intense and thorough research, furnishing the reader with as much accurate historical reference and detail as possible. This directly impacts the author's characters and their motivations for they can only act as only they could in that time and place to which they are consigned. As a result, Eco states that history books never make the periods come alive as clearly as do historical fictions. I agree and add that through the work of historical fictionists, history becomes more comprehensible, more pertinent, more entertaining and more enjoyable.

Writing historical fiction allows the author to explore people's motives, which don't often appear in primary sources. When we study the past, we know what people did, but we are often left wondering why they did it. Historical fiction can speculate on the answers to the questions left in the void history often leaves behind, and, according to Emily Miller Budick [15], it is in this void "in which a fantasy of reality emerges": a fabulation. Historical fiction authors know that this tack of bending the "truth" can be a dangerous one to take. Budick contends that they know that "the difference between valid fiction and escapist fiction is the way in which this void of fiction is filled. It depends on how the 'fantasizer' can recover the historical thread that has been severed and how he/she reconnects the fiction to the historical realm that has been vacated."

Unusual for a "non-Canon" literature genre, historical fiction is being welcomed and embraced by literati more and more. Unfortunately, historical fiction is also mostly often perceived in academia as literature's poor relation, and consequently not worthy to be considered a scion on the Canon's family tree. As previously noted, Naomi Jacobs thinks that since historical fiction writers utilize "the art of 
lying" as a main writing tool, the genre is often viewed as an inherently inferior, when compared to more so-called "sophisticated" genres that better challenge imaginative thinking. It is this criticism of historical fiction, it being a form that tells lies that still lead to no "surprise endings," that propels its writers to deceive their readers, or otherwise incur their doubts.

The bias against historical fiction includes a perception that the insertion of historical figures in a piece of fiction inhibits the writer's ability to imagine beyond historical fact. This bias has prevented historical fiction, a popular literary form since its inception in the $19^{\text {th }}$ Century, from achieving its place in literary history or the critical esteem it deserves. It is an unfair demotion, since, as Rhona Martin [16] points out, "far from being easier to write than contemporary fiction, it must be faced that historicals are arguably more demanding."

Historical fiction is the most natural form of storytelling. Richard Lee concurs, stating, "Anecdotes, stories, and lore that shape characters out of the past either glorify or demonize the past. But rarely are we worried about the precise truths of these stories, and certainly not in the opinion of an historian's verifiable sense of truth." Rather, historical fiction writers are more concerned that these stories are amusing, or interesting to tell; historical fiction readers are more concerned the past come alive and come back to them. Both writers and readers are more concerned that a piece of historical fiction allows them to visit a specific version of the past so that they can hold it dear and so that it is not lost or forgotten. That is historical fiction, or what Lee calls "the most fundamental human literary need ... [for it is an] artistic form that springs forth from a primal impulse to give shape to the past and bring alive into the present." Historical fiction transports readers to the past and makes them feel what otherwise would remain dead and lost. The very best of historical fiction does indeed present its reader with a kind of a "truth" - a truth of the past that is not the truth of the history books, but a bigger truth, a more important truth - a truth of the heart.

\section{The Writer as Manipulator}

Heretofore, the creative writer has been largely ignored in, or perhaps has chosen to ignore, a literary-linguistic dialectic. To that end, I defer to Greg Meyers [17] who argues, "A basic framework for the analysis of politeness can be extended to written texts, if one can analyze the relations of writers and readers instead of assuming a simple two-sided Speaker/Hearer relation. [Literature can] illustrate many of the categories Brown and Levinson devised for spoken interactions." With Meyers in mind, and in attempt to explore how Brown and Levinson's politeness theory and creative writing intersect, I have coined a term - the Scheherazade Dynamic - which illustrates how the relationship that exists between interlocutors in oral communication mirrors the same relationship between author and reader in creative fiction, specifically, linguistic theory in conjunction with reader response theory. Scheherazade's simple and moral tale has inspired many literary re-workings and theories, most notably feminist theory. But by casting a wider critical net, we are able to see how Scheherazade's story represents the intersection of the creative writer and politeness theorist. Moreover, the dynamic between oral interlocutors mirrors not only the dynamic between authors and readers, but also the dynamic between online instructors and online students.

To understand this dynamic, we need to revisit to The Arabian Nights. In that story, Sultan Shahriar, who is vengeful, shamed, and melancholic because his first wife was found guilty of adultery, decrees he will marry a new virgin daily and then execute her the morning after the wedding night. He kills many women by the time he marries Princess Scheherazade. In an effort to dissuade the Sultan from executing her the next day, a resourceful and courageous Scheherazade begins telling episodic and anecdotal stories on her wedding night, stories based on her knowledge of philosophy and history. A fascinated Shahriar lies awake and listens as Scheherazade tells her first story. The night passes and when a clever Scheherazade stops in the middle of her story, the Sultan commands her to finish. But the manipulative Scheherazade replies there is not time, as dawn is breaking. So, Shahriar spares her life for one day and allows her to finish the story the next night.

The following night, Scheherazade finishes the story, and then starts a second, even more exciting tale which she stops telling halfway through, once again at dawn. The Sultan again spares her life for one more day in order to finish the second story, and the next and the next. This unusual relationship continues: Shahriar thinks he controls Scheherazade's actions, who must tell her stories to stay alive, whereas it is Scheherazade who is in control, as she forestalls her inevitable fate by linking story to story, thus knowingly controlling Shahriar's actions and reactions.

At the end of 1001 nights, and after 1000 stories, Scheherazade tells Sultan Shahriar that she has no more tales to tell him. But no matter, for during those 1001 nights, the Sultan has fallen in love with Scheherazade. By holding Shahriar's interest in both the allure and beauty of her stories, Scheherazade avoids her execution and also inadvertently educates the Sultan and broadens his sympathies. George Slade [18] writes that Scheherazade "disarms him and changes his negative disposition to life and women" as well. The brutal and insensitive tyrant whom Scheherazade confronts has been tricked into allowing his own positive traits to emerge at the hands of his new wife. Slade adds that "knowledge becomes power when it is exercised; Scheherazade resorts to storytelling and suspense to captivate the Sultan, keeping him thereby from further brutality ... [thus] storytelling becomes an agent of change ... a good story means survival, a bad one could mean death."

It is as an "agent of change" that best illustrates the shared dynamic between interlocutors in oral communication and author and reader in creative fiction. The imbedded 
storylines in Scheherazade's tale allow us to be witnesses to a storyteller's manipulation of her audience. Though the story of The Arabian Nights is one featuring a teller of tales in the oral tradition, Scheherazade nevertheless remains a storyteller; it is that act of storytelling to achieve an effect on, or an outcome for, an audience that I focus on.

The notion of an interlocutor's independent, autonomous nature is at the basis of Brown and Levinson's [19] definition of Negative Face: "The basic claim to territories, personal preserves and preservation, the right to non-distraction, freedom from imposition, freedom of action and self-determination; the want of every competent adult member that his actions be unimpeded by others." Though couched in terms that apply to oral communication, Brown and Levinson's concept of Negative Face can also be conveyed in the non-verbal forms of written communication, in particular creative writing.

Traits such as non-conformity, self-promotion, autonomy, and independence are all part of B/L's Negative Face and they also partially define the creative writer. Brown and Levinson write

\subsubsection{First Distinction: Kinds of Face Threatened}

Those acts that primarily threaten the addressee's (H's) negative face want, by indicating (potentially) that the speaker (S) does not intend to avoid impeding H's freedom of action.

(i. a.) Those acts that predicate some future act $\mathrm{A}$ of $\mathrm{H}$, and in doing so doing put some pressure on $\mathrm{H}$ to do (or refrain from doing) the Act of $\mathrm{A}$.

Scheherazade's desire to be left alone and allowed to live is an example of her Negative Face, just as Shahriar's desire to remain autonomous is an example of his Negative Face. Scheherazade knowingly challenges (impedes) the oblivious Sultan and his rule, his status, his "face." Scheherazade becomes covertly uncooperative, for she has her own agenda. Scheherazade (Speaker/Storyteller) manipulates Shahriar (Hearer/Reader), albeit covertly, to refrain from performing an act, in this case executing her. She raises provocative topics in her stories quickly swaying the Sultan off his course, or his "negative want." In the end, having been made a wiser and kinder man by Scheherazade and her tales, the Sultan spares her life, and makes her his queen.

The Scheherazade Dynamic refers to the autonomy, self-determination, and ownership part of Brown and Levinson's definition connecting it to creative writers who exhibit these same traits which they wield over their readers. As seen by the Brown and Levinson model, speakers, Scheherazade, and creative writers all gain control of their audiences and manipulate them by asserting this autonomy in order to achieve a desired effect, that is to impact the imagination of the reader. There is a particular manipulative autonomy inherent in all creative writers, for as Mark Runco [20] states, "Writing provides more opportunities for self-expression and problem resolution than other domains of creative work." What could be a better example of the
Negative Face of creative writers than their desire to be allowed to express themselves or to determine their own literary destinies? This view of creative writing being autonomous is based in the notion that all writers - in particular creative writers - begin on a personal level including the desire not only to please others, but also to isolate and protect themselves.

Conversely, as part of B/L's dichotomy, all writers also start with Positive Face, filled with self-identity, interpretations, discretions, and intentions. Runco writes that all creative writers share the following traits:

- Original interpretation of experiences

- $\quad$ Ego strength; self-confidence; autonomy

- Discretion; originality and effectiveness

- Intentions and personal interests

Admittedly, we creative writers are often also eccentric, resulting from not only non-conformity and but also autonomy and independence. This is Negative Face, symbolized by Scheherazade in her individualistic quest for survival. In an effort to assert ownership over her own fate, she challenges the autonomy of the Sultan. In effect Scheherazade's is a face-threatening act and, as Slade offers, by resurrecting the life or death metaphor that measures the efforts of most creative writers, "[Good] storytelling quite literally saves Scheherazade's life.” According to Brown and Levinson, freedom of choice and action are impeded when Negative Face is threatened. The Sultan's Negative Face (his independent treatment over his wives and his control of their destinies, free from impunity) is subordinated by Scheherazade's stronger autonomy, her ego-strength, if you will. The Sultan's Negative Face becomes threatened when Scheherazade does not avoid nor intend to avoid obstructing his power. The Sultan, in a sense, is rendered powerless, subconsciously submitting to Scheherazade's stronger will, because he trusts her. It is the trustworthiness (or untrustworthiness) or an author/speaker, which affects the writer-speaker/speaker-listener dynamic and impacts the autonomy of all.

The Sultan does not know whether the tales Scheherazade tells are the truth or not. He has no way of telling. But he enjoys them as an eager child might, never questioning their validity. Then again, what possible difference could it make to him if they were lies or truth or a hybrid of the two? And although Scheherazade doesn't lie per se, she does hide her secret motive from the Sultan, manipulating him, finagling him, and easing him out of his vindictive revenge on women and his prejudice

Creative writers need to draw on ego strength (a type of self-confidence) to resist the pressure to conform and to think and act as originals. This self-confidence - or autonomy, as defined by Brown and Levinson - allows a person's originality to be expressed rather than inhibited. Mark Runco argues that originality most likely occurs "when the individual is autonomous and unconventional." Creative writers have a preference for complexity and self-determination. This trait parallels that of the 
self-confident Scheherazade: she too remains autonomous, striving to remain in control of her destiny. She too is unconventional, creatively diverting the Sultan from his goal. Her stories, like the stories of many creative writers, are complex, the purposes of which are not only to entertain, but to serve personal needs, a prime example of the preservation of Negative Face.

True, a piece of fiction is finite and does not really enter into an actual dialogue with its reader: speaking and creative fiction remain two distinct styles of communication. It is this restriction that retards a pure application of the Brown and Levinson theory. But if we implement a broader view of politeness itself, the fact remains that a communication exchange is a constant dialectic aiming toward mutual understanding, and the effect this has on a reader is the same as it is on a listener. An author becomes the disembodied voice of the reader, a manipulative, autonomous phantom invading the reader's space. In a sense, a literary text does communicate to its reader a kind of intercourse, and because of the many interpretations readers have of a given story, it can be argued that this intercourse becomes a dialogue. This new dynamic suggests that the work is not a one-way street, but rather a two-way form of communication, a dynamic entity. Joseph Kestner [21] argues that a literary work is therefore "extensive beyond itself," or as Wayne Booth [22] submits, "it becomes the unification of dramatic necessity and rhetorical function."

\section{Conclusions}

Arguably, historical fiction is a lie grounded in fact, but one could also argue that all fiction is a lie grounded in fact. All fiction - for that matter, all art - is at odds with itself in that it seeks at the same time accuracy and illusion. So it is unfair to define historical fiction as merely as a genre based on lies - or fabulations - since it can also be argued that fabulating is a defining characteristic of all fiction. All art, particularly fiction, is about contradiction. All artists - visual and performing - create illusions, but these illusions must be convincing and accurate, accurate as far as their intent is concerned, otherwise they are useless. The "lie of art" can show more "truth" than many examples of easily verifiable fact, and the "art of lying" is the method by which that truth is achieved. As a result, authors of historical fiction enjoy a certain amount of literary license in that though they presumably know historical facts, they are not bound by them.

Historical fiction writers are not in the truth game, but rather in the believability game. Historical fictionists don't finagle, invent, manipulate or fabulate just because they can, they take these tacks because they should, for the inner truths achieved in a piece of historical fiction are constructed from lies and fabulations, and very often are inspired by historical inaccuracies to begin with.

As is the case when we read pure fiction, if we enjoy reading historical fiction, then we are in the hands of the historical fiction writers who manipulate and control us and our vision through their own, and so we are largely at the mercy of these writers who have license to lie and manipulate without impunity. It is the writer as manipulator who feeds into Brown and Levinson's politeness theory, specifically their concept of Negative Face.

The dynamic shared between Scheherazade and the Sultan mirrors how a reader acquiesces to the manipulative autonomy of the writer; author choices such as style switching, provocative language, and offensive topics can challenge a reader's status. Once readers willingly allow the prose of a writer to enter their worlds, they acquiesce to the writer, or as Janet Burroway [23] believes, "We tacitly accept our role as a member of an unspecified audience," and they who were self-determined become victim, sometimes willingly, sometimes unwillingly, to that writer's autonomy.

Writers risk that every reader will impose face threatening acts on their autonomy by rejecting their storytelling technique and/or style, or even the authority by which they manipulate and fabulate to tell their tales. Both parties ultimately understand and accept this. It is the embodiment of the dynamic between storyteller and audience, between Scheherazade and the Sultan. It is fabulation and manipulation working together to draw in the audience.

Reactions to an author's work and the threats they make to readers' Negative Face become part of the ongoing discourse, in which individuals represent, or believe they represent, the stance of the author. As the interlocutors in Brown and Levinson's concept of Negative Face pose threats to each other's Negative Face orally, those interlocutors in written communication pose threats to an author's Negative Face in written form, via published rebuttals in journals, blogs, letters to editors, Facebook exchanges, online chat rooms, etc. Even after authors die, their work can still pose threats to readers' Negative Face, which also initiates a discourse on a discourse, since as Kestner explains, "The text and its interpretations [are] two languages of the same language. The relation between the two discourses reveals the inseparability of time and space." And it is immaterial whether or not living (or dead) authors, or their readers, are aware of the reactions to threats made to each other's Negative Face, since Brown and Levinson never state whether or not both interlocutors need to be aware of the other's reaction(s).

Though the Sultan subordinates himself to Scheherazade's authority, and though he willingly, though perhaps subconsciously, acquiesces to her better judgment, he still sits in judgment of the storyteller Scheherazade and her stories. Martin Lindauer [24] states that "a close relationship therefore exists between creative authors, creative works and readers," and so from this relationship comes a willingness of an audience to subjugate themselves to the manipulation and authority of a storyteller. This relationship is defined for oral communication in politeness theory as Negative Face, but it is also key to the dynamic between creative writers and their readers.

In the final analysis, the value of any historical fiction, like 
all fiction, rests on a valid portrait of time, place, and character. If a piece of historical fiction elevates the reader's understanding of the human condition, it justifies itself beyond moral concerns such as lying and manipulating. Judge historical writers and their work by these tropes: is it convincing; is it artistically satisfying; does it meet the requirements of its own aesthetic? If historical fiction awakens our imagination to a sense of the past, then it has value, regardless if the authors lie or whether those authors manipulate readers and impose their authority on them.

\section{REFERENCES}

[1] Levine, Paul. E. L. Doctorow. New York: Methuen, 1985. Print.

[2] Manzoni, Alessandro. On the Historical Novel. Trans. Sandra Bermann. Lincoln, NE: U of Nebraska P., 1984. Print.

[3] De Groot, Jerome. The Historical Novel. New York: Routledge, 2010. Print.

[4] Scholes, Robert. Fabulation and Metafiction. Urbana, IL: U of Illinois P, 1979. Print.

[5] Carr, Edward Hallett. What Is History? New York: Knopf, 1961. Print.

[6] Schele, Linda. "Is History Objective?" Mesolore, Web. 22 Feb. 2015

[7] Hutcheon, Linda. A Poetics of Postmodernism: History, Theory, Fiction. New York: Routledge, 1988. Print.

[8] Brown, Joanne and Nancy St. Clair. The Distant Mirror: Reflections on Young Adult Historical Fiction. Lanham, MD: Scarecrow P, 2006. Print.

[9] Hollowell, John. Fact \& Fiction: The New Journalism and the Nonfiction Novel. Chapel Hill, NC: U of North Carolina P., 1977. Print.

[10] Doležel, Lubmír. Possible Worlds of Fiction and History: The Postmodern Stage. Baltimore: Johns Hopkins P., 2010.
Print.

[11] Lee, Richard. Historical Novel Society. Home Page, Web. 25 Jan. 2015.

[12] Craney, Glen. "Lies, Damn Lies, and Historical Fiction." History into Fiction, 7 August 2010. Web. 17 Feb. 2015.

[13] Jacobs, Naomi. The Character of Truth: Historical Figures in Contemporary Fiction. Carbondale, IL: Southern Illinois U P, 1990. Print.

[14] Rozett, Martha Tuck. "Constructing a World: How Postmodern Historical Fiction Reimagines the Past." $A$ Journal of Literature History and Philosophy of History. 25.2 (1996): 145-164. Print.

[15] Budick, Emily Miller. Fiction and American Consciousness: The American Romance Tradition. New Haven: Yale U P, 1989. Print.

[16] Martin, Rhona. Writing Historical Fiction. London: A.C. Black, 1995. Print.

[17] Meyers, Greg. "The Pragmatics of Politeness in Scientific Articles." Applied Linguistics. 10.1 (1989): 1-35. Print.

[18] The Arabian Nights. Ed. George Slade. New York: Barnes and Noble, 2007. Print.

[19] Brown, Penelope and Stephen C. Levinson. Politeness: Some Universals in Language Use. New York: U of Cambridge P, 1992. Print.

[20] Runco, Mark A. Markrunco.com, Web. 25 Feb. 2015.

[21] Kestner, Joseph A. The Spatiality of the Novel. Detroit: Wayne State U P, 1978. Print.

[22] Booth, Wayne C. The Rhetoric of Fiction, $2^{\text {nd }}$ ed. Chicago: U of Chicago P, 1983. Print.

[23] Burroway, Janet. Writing Fiction: A Guide to Narrative Craft. Boston: Middleton and Brown, 1987. Print.

[24] Lindauer, Martin S. "Literary Creativity and Physiognomy: Expressiveness in Writers, Readers and Literature." The Psychology of Creative Writing. Eds. Scott B. Kaufman and James C. Kaufman. NY: U of Cambridge P, 2009. 117 - 45. Print. 